\title{
Beyond Committees: Parliamentary Oversight and Coalition Government in Britain*
}

\author{
Shane Martin ${ }^{1}$ and Richard Whitaker ${ }^{2}$ \\ ${ }^{1}$ Department of Government, University of Essex, UK \\ ${ }^{2}$ School of History, Politics and International Relations, University of \\ Leicester, UK
}

\begin{abstract}
A legislature's ability to engage in oversight of the executive is believed to derive largely from its committee system. For example, powerful parliamentary committees are considered a necessary condition for the legislature to help police policy compromises between parties in multiparty government. But can other parliamentary instruments perform this role? This paper suggests parliamentary questions as an alternative parliamentary vehicle for coalition parties to monitor their partners. Questions force ministers to reveal information concerning their legislative and extra-legislative activities, providing coalition members unique insights into their partners behaviour. To test our argument, we build and analyse a new dataset of parliamentary questions in the British House of Commons covering the 2010-15 coalition. As expected, government MPs ask more questions as the divisiveness of a policy area increases. Legislatures conventionally considered weak due to the lack of strong committees may nevertheless play an important oversight role through other parliamentary devices, including helping to police the implementation of coalition agreements.
\end{abstract}

Keywords: Parliaments, Legislatures, Coalitions, Oversight, Parliamentary Questions, Committees

${ }^{*}$ This research was supported by British Academy Grant No. MD150032. We are extremely grateful to Andrew Jones for help in putting the dataset together for this paper. We thank Cristina Bucur, Andrew Jones, Jon Slapin, David Willumsen and the journal's reviewers for comments on earlier drafts. All errors remain our own. 
In many parliamentary regimes, coalition governments (cabinets comprising more than one political party) are common. Scholars have long been intrigued by which parties participate in such governments (Müller and Strøm 2003). More recently, political scientists have explored how coalition governments function once formed. Coalitions typically form after interested parties bargain over and reach a coalition agreement. This agreement must be policed because individual ministers may have an incentive to deviate from the agreement, toward the preferences of the party to which they belong (Thies 2001). ${ }^{1}$ Political institutions provide a mechanism by which, in the parlance of agency theory, the principal (the coalition) monitors the agent (the minister), thus ensuring the stability of the coalition. Parliamentary committees' engagement in the legislative process is one important means by which parties in coalition government keep tabs on each other (André et al. 2016; Martin 2004; Martin and Vanberg 2004, 2005, 2011; Zubek 2015).

We contribute to the literature on legislatures and coalition monitoring by suggesting that parliamentary questions (PQs) are another potential instrument for coalition parties to monitor their partners in coalition government. ${ }^{2}$ PQs are a common feature of many legislatures, allowing parliamentarians to formally ask questions of, and receive answers from, members of the executive. PQs force ministers to reveal information on past, current and future activities.

To test our proposition that parties in a coalition government use PQs to keep tabs on each other, we build and analyse a new dataset of parliamentary questions in the British House of Commons covering the 2010-15 coalition government. The British Parliament is commonly seen as one of the weakest democratic national parliaments in terms of its ability to hold the cabinet to account. The growth of the Cabinet's legislative powers the efficient secret (Cox 1987) - and high levels of party voting unity (Kam 2009) means that the executive dominates the legislative process. A weak committee system reduces the ability of the chamber to provide oversight of the government (Norton 2013). Westminster's committees remain the poor cousin of many European parliamentary committee systems (Martin 2011a). As Kreppel (2014: 95) notes in reviewing the comparative literature on legislative typologies, 'the U.S. Congress and the British Parliament serve as the emblematic examples of a strong congress and weak parliament respectively', although recent scholarship has challenged this view by showing how UK backbenchers can exert influence over the government (Russell et al. 2016; Russell and Cowley 2016; Russell

\footnotetext{
${ }^{1}$ The comparative literature on political coalitions uses various terms including 'policing', 'monitoring', 'keeping tabs', 'controlling', and 'constraining'. We use these terms interchangeably throughout the paper to describe the phenomenon by which parties in coalition government seek to minimise agency loss and ensure that all members of the coalition cabinet are implementing the coalition agreement.

${ }^{2}$ Scholars have identified a number of extra-legislative mechanisms by which parties in coalition government can keep tabs on each other, including detailed ex ante coalition agreements (Müller and Strøm 2008), the strategic allocation of junior ministers (Thies 2001), and sharing deputy prime ministerships among coalition parties (Saalfeld 2000). Understanding of the relative popularity of the various mechanisms remains largely unexplored.
} 
and Gover 2017). The emergence of a coalition government in the United Kingdom for the first time since 1945 provides a challenging case to study the use of legislative tools for intra-coalition monitoring. To anticipate, we find that MPs ask more questions of ministries held by their coalition partner as the level of policy divergence between the coalition partners increases.

A number of important consequences flow from our argument and findings. Based largely on the US Congressional model, comparative legislative scholars have long focused on committee systems to measure a legislatures potential power and influence (Martin 2014). Although strong committees undoubtedly strengthen legislatures vis-à-vis the executive (Strøm 1990), they are perhaps not a necessary condition for oversight of the executive by the legislature. Other legislative instruments provide alternative avenues by which the legislature can hold ministers accountable. Thus, legislatures conventionally considered weak due to the lack of strong committees may nevertheless play an important oversight role (not least during times of coalition government), as we believe the British case demonstrates. Relatedly, our arguments regarding the strategic use of PQs shed light on the importance of monitoring extra-legislative ministerial activity. Existing scholarship on legislatures and coalition government (discussed below) stresses the ability of legislatures to scrutinize and amend a ministers proposed legislation. Yet, much of modern government is based on post-legislative delegation to the minister and ministries (Huber and Shipan 2002). PQs allow parties in coalition to keep tabs on these extralegislative activities of ministers and their officials. The behaviour of a minister may be different at the policy implementation stage if the partner party is not continuing to keep tabs on the minster and her ministry. Finally, our research provides much needed insights into how coalition government operates in what many consider an archetypical majoritarian political system (Lijphart 2012). Even here, parliament plays a more significant role than heretofore acknowledged.

The remainder of the paper is organized as follows. Next, we briefly review the literature on coalition delegation and oversight. Section 3 introduces our argument that PQs are a potential vehicle to keep tabs on the activities of ministers in coalition government. Section 4 briefly introduces the British case. Section 5 presents the data and analysis. We conclude the paper with a review of our findings and suggestions for future research.

\section{Delegation and Oversight in Coalition Government}

Coalition government requires governing parties to cooperate over the production and implementation of public policy. At the same time, potential for conflict exists because parties in a coalition govern in the shadow of elections where they will typically compete directly against each other for votes. Moreover, individual ministers and the parties to which they belong usually have their own policy preferences. Coalition government is 
only possible because parties are willing to compromise on these preferences in order to govern jointly. In many countries, a formal coalition agreement sets out the compromise (Müller and Strøm 2008).

It falls to individual cabinet ministers to implement the coalition agreement. In the parlance of principal-agent theory, a cabinet minister acts as the agent of the cabinet. Ministers are particularly powerful in parliamentary regimes, effectively acting as gatekeepers to policy initiation and implementation within their own portfolios (Laver and Shepsle 1994). A coalition government delegates implementation of the agreed-upon policies not only to cabinet members of their own party, but also to their coalition partners ministers (Thies 2001). Ministers in a coalition government have a particular incentive to deviate from the agreed-upon policy positions exactly because different parties tend to prefer different policies.

To avoid agency loss, principals (in this case, the coalition government) look to a number of ex post control mechanisms (Strøm et al. 2010). Junior ministers may be strategically appointed to shadow and keep tabs on the cabinet ministers of the coalition partner (Thies 2001). Giving deputy prime ministers a coordinating responsibility and appointing one from each coalition party serves a similar purpose (Saalfeld 2000). Inner cabinets, specialized cabinet committees, and permanent coalition committees manage any tensions over implementation of the agreement and unanticipated events (Müller and Strøm 2008).

Recent studies have pointed to the importance of the legislative process as a means to police the coalition agreement. In a seminal contribution, Martin and Vanberg (2011) suggest that the legislative process serves as a structural solution to the keeping tabs problem inherent to coalition government. Coalition cabinets introduce bills on which the coalition partners agree, early in the term and postpone more controversial bills (Martin 2004). Proposed legislation on which there is disagreement among the coalition partners faces greater scrutiny during the legislative process (Martin and Vanberg 2004). Pointing to the crucial role of committees in the legislative process, more contentious proposed legislation among coalition partners is more heavily amended at the committee stage (Martin and Vanberg 2005). Parliaments with strong committees, Martin and Vanberg (2011) suggest, are uniquely positioned to police coalition agreements, just as committees provide an informational advantage in legislatures more generally (Krehbiel 1991). That parties strategically assign committee chairs to keep tabs on their coalition partners provides further evidence of the committee structures central position in intracoalition monitoring (Carroll and Cox 2012). André et al. (2016) argue that coalition parties' need to keep tabs on each other explains legislative organization, in particular, the committee system's structures and powers. Where multiparty government is the norm, legislatures tend to develop strong committees. Zubek (2015) finds that reforms expanding committee power are most likely when ideological conflict within the coalition 
government is greatest.

In summary, we know that coalition government creates unique challenges to monitor individual ministers and police the coalition bargain. Democracies with experience of coalition government develop rules and institutions to mitigate ministerial autonomy. We know also that the legislative process facilitates coalition monitoring, assuming a strong committee system. Yet committees are just one feature of legislative organization. In the next section, we propose that other legislative instruments may serve as a mechanism for parties in coalition government to keep tabs on each other.

\section{PQs as a Coalition Policing Mechanism}

A common feature of legislative organization, particularly in countries operating a parliamentary system of government, is the ability of members of the legislature to ask questions of, and receive answers from, members of the government (Franklin and Norton 1993). A legislature may have dedicated question time on the floor of the chamber during which cabinet ministers make themselves available to reply to questions posed by legislators. Question time can be contrasted with other plenary activity, such as the law-making process, motions, statements or general debates. In addition, legislators in many countries are able to table written PQs. In this case, legislators submit a question in writing and a written reply is provided by the relevant minister. Answers to both oral and written questions may be published as part of the official record. In European legislatures, written questions are now much more voluminous than oral questions, likely due to the plenary bottleneck and lack of time to ask oral questions (Cox 2006; Rozenberg and Martin 2011). The process of asking a written PQ takes the following generic format in most democratic legislatures:

1. A parliamentarian (or a staffer with authority to act on the parliamentarians behalf) poses in writing a question to a particular minister via the parliamentary administration.

2. The parliamentary administration reviews the question and determines whether it is correctly formatted, follows the rules, and is directed at the appropriate minister. If allowable, the question is forwarded to the relevant government department. Otherwise, the question is returned to the member unanswered.

3. Officials within the department draft a reply, with typically either a senior official or the minister reviewing drafts.

4. The answer to the PQ is forwarded to the parliamentary administration from where it is communicated directly to the questioner and published in the official proceedings of the parliament. 
PQs are acknowledged as an important tool to allow opposition parties to hold the government to account (Russo and Wiberg 2010; Wiberg 1994). As the website of the UK House of Commons notes, PQs are 'used to obtain detailed information about policies and statistics on the activities of government departments.' A series of country-specific studies indicate that PQs are a useful mechanism for allowing the opposition to obtain information on government behaviour and performance (for an overview, see Martin 2011b). Wiberg (1994) suggests that the greater levels of governmental activity drive the observed increase in PQs identified in many European legislatures. Proksch and Slapin (2011) discovered that written questions in the European Parliament are an important source of control and oversight for national opposition parties. Thus, the underlying assumption in the study of PQs is that they serve as an important instrument of oppositional influence. ${ }^{3}$

Our core argument is that PQs are more than simply a tool for opposition influence. PQs, we suggest, provide a potential mechanism for parties in coalition government to keep tabs on each other's ministers. Legislators from notional coalition party a monitor policy implementation by ministers from notional coalition party $b$. When members from the governing parties fear or detect deviation from the coalition agreement during implementation (either in terms of proposed legislation or the executive implementation of policy), they can table PQs to both obtain clarifying information and send a signal to the minister. In response to such PQs, the minister corrects the policy drift. Since we can expect that the drift in implementation is more likely in areas in which coalition parties are more divided, we would expect more questions in such policy areas. ${ }^{4}$

How exactly do PQs mitigate agency loss in coalition politics? The key to preventing the threat of agency loss in coalition government is to empower the principal to monitor the agent by overcoming the informational advantage held by the agent. In other words, the lack of information on what the agent is, or is not, doing is a key disadvantage faced by most principals. PQs provide oversight through their ability to extract specific highquality information on the past, current and future actions of ministers and ministries. Thus, in the parlance of McCubbins and Schwartz (1984), PQs provide a form of policepatrol, allowing monitoring and reporting of information not otherwise easily available. Written PQs reduce the informational disadvantage inherent in cabinet government by providing the legislature a tool to find out exactly what is, or is not, going on within the ministry. The act of asking a PQ may send a signal to the minister that the other party or parties in the coalition are closely watching; ultimately incentivising the minister to return to the coalition agreement.

\footnotetext{
${ }^{3}$ The assumption that PQs are exclusively a tool for opposition influence is easily debunked by the casual observation that many PQs come from government backbenchers (in many parliaments the norm is for government ministers not to ask PQs of each other).

${ }^{4}$ We follow the comparative coalition government literature in making the assumption that policy differences across parties surpass policy differences within a single party. We return to the issue of intra-party policy differences in our empirical analysis and the conclusion.
} 
To illustrate the potential of PQs to serve as a mechanism for governing party MPs to keep tabs on ministers, consider the following written PQ from the House of Commons, posed by a Liberal Democrat MP to Iain Duncan Smith, a Conservative Party cabinet minister. The topic is welfare reform, a well-known source of tension between the two parties (Laws 2016; Page 2015: 95):

Sarah Teather: To ask the Secretary of State for Work and Pensions what comparative assessment he has made of the effect on the relative health of claimants and their dependents of changes to the jobseeker's allowance sanction regime introduced in October 2012. [172926] (Hansard 29 October 2013: Column 459W).

The example above illustrates well how written PQs provide a mechanism for the detailed scrutiny of ministers actions and policies. Certainly, different styles of PQs exist. Some questions may have a fundamentally local focus (for example, asking about a hospital in a members constituency); some may clearly be focused on national policy (for example, asking about the National Health Service), while other PQs may focus on more international policies (for example, international development). Regardless of the specific style of the PQ (Martin 2011b; Kellermann 2016) all PQs have a monitoring capacity. Fundamentally, PQs serve to extract information from the executive, be it on the effect of government policy on a local hospital, the health service or British overseas development aid. PQs, and in particular written PQs, are an ideal mechanism for intra-coalition monitoring for a number of reasons:

1. Ministers must answer a written question, typically in a timely fashion (one week in the British case), and must provide a truthful answer. Because written PQs can request very specific information (as the above example illustrates) and allow time for the answer to be researched, ministers have less opportunity to say that the information requested is not available. For example, the official United Kingdom civil service guidance on drafting answers to parliamentary questions reminds civil servants to:

Never forget Ministers' obligations to Parliament which are set out in the Ministerial Code: 'It is of paramount importance that Ministers give accurate and truthful information to Parliament, correcting any inadvertent error at the earliest opportunity. Ministers who knowingly mislead Parliament will be expected to offer their resignation to the Prime Minister. Ministers should be as open as possible with Parliament and the public, refusing to provide information only when disclosure would not be in the public interest. ${ }^{5}$

\footnotetext{
${ }^{5}$ https://www.gov.uk/government/uploads/system/uploads/attachment_data/file/61195/ drafting-pq-responses.pdf
} 
2. Tabling a written PQ, although not resource-neutral, is nevertheless a relatively costless exercise for an individual parliamentarian. It is the government who must then expend resources to answer the question. In contrast, the use of committees as a monitoring tool requires significantly more effort and resource allocation on the part of the individual MP who must join, prepare for, attend and actively participate in committee hearings if committees are to serve as a coalition monitoring device. Members may be reluctant to invest in committee work where the electoral rewards are limited (Martin 2011b).

3. PQs can extract very specific information about a minister's performance, but at a lower political cost to the government as a whole. Because being in government can be electorally unpopular (Narud and Valen 2008), governing parties tend to shy away from communicating negative news and often work hard to maintain, at least the public appearance of, government unity. Coalition oversight tools such as parliamentary committees represent a very public way to manage tensions in the relationship. In contrast, although PQs are publicly available, written PQs represent an arguably more subdued way to patrol the coalition.

4. PQs allow implementation of policy and legislation to be monitored. Legislatures delegate the details of policy implementation to ministers who may then delegate the task to civil servants (Huber and Shipan 2002; Strøm 2000). As Laver and Shepsle (1994: 13) note, coalition theory has long lacked of concern for policy implementation. It seems reasonable that any attempt to police the coalition bargain should pay attention to policy implementation. PQs can help parties explore all aspects of ministerial behaviour - including planned legislation, delegated legislation, through to the operational performance of the minister and ministry.

5. Ministers and officials are often highly sensitive to the content of PQs (Martin 2011b). As such, PQs serve as a form of two-way communication and signalling device (Schelling 1960). While the answer will provide information to the questioner, the ministry may also take note of patterns of questions and use this as a measure of the concerns and preferences of government backbenchers.

The suggestion is that PQs have the potential to be an intra-coalition monitoring device. Because PQs have the advantage of being recorded in a number of legislatures, it is possible to explore the degree to which patterns in questioning within parliaments with coalition governments align with the allocation of ministerial portfolios between parties. In other words, do patterns of inter-coalition PQs reflect the policy portfolios of most conflict between parties in the coalition or, as Martin and Vanberg (2011: 79) put it, the policy divisiveness of issues dealt with by the coalition? To explore whether PQs are used strategically to police the coalition bargain, we explore questioning patterns among 
government MPs in the British House of Commons during the 2010-2015 coalition. The next section introduces the British case.

\section{The British Case}

The United Kingdom is a parliamentary democracy, with the cabinet responsible to the directly elected House of Commons. Members of parliament (MPs) are elected by single member plurality rules, resulting typically in single party majority government. The 2010 general election produced a hung parliament and following negotiations a coalition government was formed between the centre-right Conservative Party and centrist Liberal Democrats - the first formal coalition in post-war Britain. The coalition agreement set out a programme of policies to be enacted by the government (Hazell and Yong 2012; Quinn et al. 2011). Table 1 shows how cabinet portfolios were distributed between the two coalition partners. Although an aberration in modern British politics, the coalition government operated remarkably similarly to governments in other coalition systems, with co-operation and unity punctuated occasionally by inter-party conflict over policies (Laws 2016).

Table 1: Cabinet Portfolio Distribution and Gaps Between the Coalition Parties in the 2010-15 Conservative-Liberal Democrat Coalition

\begin{tabular}{|c|c|c|c|}
\hline Portfolio/Position & Party holding ministry & $\begin{array}{l}\text { Absolute value of gap between par- } \\
\text { ties (and scale used) }\end{array}$ & Mean questions per MP \\
\hline Prime Minister & Conservative & $\mathrm{n} / \mathrm{a}$ & $\mathrm{n} / \mathrm{a}$ \\
\hline Deputy Prime Minister & Liberal Democrat & 1.95 (Constitutionalism) & 1.2 \\
\hline Foreign Office & Conservative & 0.92 (Foreign office) $^{*}$ & 12.8 \\
\hline Treasury & Conservative & 0.42 (State involvement in economy) & 10.9 \\
\hline Justice & Conservative & 0.26 (Social-Liberal Conservative) & 11.9 \\
\hline Home Office & Conservative & 2.92 (Nationalism) & 14.2 \\
\hline Defence & Conservative & 3.89 (Militarism) & 9.7 \\
\hline Business, Innovation and Skills & Liberal Democrat & 0.93 (Free market economy) & 12.4 \\
\hline Work and Pensions & Conservative & 1.31 (Welfare state) & 8.5 \\
\hline Energy and Climate Change & Liberal Democrat & 1.64 (Environmental protection) & 8.1 \\
\hline Health & Conservative & 0.93 (Free market economy) & 23.5 \\
\hline Education & Conservative & 0.54 (Education spending) & 12.3 \\
\hline $\begin{array}{l}\text { Communities and Local Gov- } \\
\text { ernment }\end{array}$ & Conservative & 0.56 (Decentralisation) & 9.7 \\
\hline Transport & Conservative & 0.93 (Free market economy) & 13.1 \\
\hline $\begin{array}{l}\text { Environment, Food and Rural } \\
\text { Affairs }\end{array}$ & Conservative & 0.64 (Environment and agriculture) $^{*}$ & 11.0 \\
\hline International Development & Conservative & 1.37 (Internationalism) & 5.5 \\
\hline Northern Ireland & Conservative & 0.56 (Decentralisation) & 0.9 \\
\hline Scotland & Liberal Democrat & 0.56 (Decentralisation) & 0.8 \\
\hline Wales & Conservative & 0.56 (Decentralisation) & 0.9 \\
\hline $\begin{array}{l}\text { Culture, Olympics, Media and } \\
\text { Sport }\end{array}$ & Conservative & 0.93 (Free market economy) & 5.9 \\
\hline
\end{tabular}

Note: gaps are calculated using scores created by the Lowe et al. (2011a) transformations of MARPOR data. *Indicates a scale created by the authors using the Lowe et al. (2011a) approach. Details of the MARPOR codes on which these new scales are based can be found in the Supplementary Material, Table S1.

While Westminster's committees have been strengthened in recent years, such as 
through the ability for public bill (legislative) committees to hold hearings (Kelso 2009) and the election of select committee chairs in secret ballots of all MPs (Russell 2011), they remain less influential than committees in many European parliaments (Martin 2011a). At the same time, United Kingdom cabinet ministers are collectively (for the cabinet's decisions) and individually (for their respective portfolios) responsible to parliament. A system of parliamentary questions is one means by which this responsibility is put into effect (Franklin and Norton 1993). Prime Minister's Questions (PMQs) is the highlight of the parliamentary week, and one of the most important means by which the opposition can challenge the government (Bevan and John 2016) and win political support (Bates et al. 2014). Written questions are asked in large numbers in the UK Parliament. Scholars have recognized the potential of PQs records to provide unique and exact insight into the preferences and concerns of individual MPs. For example, Bird (2005) explores whether PQs are used as a tool to represent gendered interests, Saalfeld (2011) and Saalfeld and Bischof (2013) suggest that PQs at Westminster may be a tool to represent the interests of visible minorities, as does Kolpinskaya (2017) with reference to religious interests. Kellermann (2016) finds that MPs ask PQs to signal effort, rather than as a form of constituency service (Martin 2011a).

In what follows, we assess how far PQs are used as a tool for coalition parties to keep tabs on their coalition partners. Based on our arguments above about the potential of PQs as a coalition monitoring tool, we expect coalition partners to target questions strategically where the policy divergence within the coalition is greatest. Specifically, we would expect Liberal Democrat MPs ask questions of Conservative ministers and Conservative MPs ask questions of Liberal Democrat ministers in greater numbers on topics where there are particularly high levels of ideological conflict between the coalition partners.

\section{Data and Analysis}

To test our argument, we build and analyse a new dataset of written PQs in the British House of Commons between the 2010 general election and the 2015 general election. This amounts to 190,549 PQs. Table 2 shows how written PQs were distributed by political party. The opposition Labour party asked more questions than any other party (by almost double). The figures for the two governing parties are lower but given the high proportions of these parties MPs involved in government at some level, this is perhaps unsurprising.

To test our expectations, we constructed a dyadic dataset that, following the approach used by Proksch and Slapin (2011), includes all combinations of backbenchers and government departments. There are 6,935 cases when restricting the data to Conservative and Liberal Democrat MPs. Each case in the dependent variable measures the number 
Table 2: Written Parliamentary Questions by Party 2010-15

\begin{tabular}{lrr}
\hline Party & Written questions & Questions per MP \\
\hline Labour & 107,795 & 418 \\
Conservative & 55,945 & 183 \\
Liberal Democrat & 10,221 & 179 \\
Scottish National Party & 3,881 & 646 \\
Green & 1,594 & 1,594 \\
Plaid Cymru & 1,331 & 444 \\
Independents & 194 & 194 \\
UKIP & 41 & 21 \\
\hline
\end{tabular}

of written PQs asked by an MP to a particular government department. This variable ranges from zero to 744 with a mean of 9.12 and standard deviation of 25.41 .

Our independent variables measure the extent to which the two coalition parties used written questions to keep tabs on each other. The main variable of interest is policy divisiveness. To assess this, we need a measure of each partys position on the policy area covered by each ministry. There are two main sources of data on party positions that are commonly used: expert judgement data (e.g. Bakker et al. 2015) and data from the Manifesto Research on Political Representation (MARPOR) project (Volkens et al. 2016). We have chosen to use MARPOR data as there are rather limited categories in the expert judgement data, leaving us without appropriate measures for a considerable number of departments. We employ the transformations to the MARPOR data set out by Lowe et al. (2011a). Their approach is superior to the scales developed by the MARPOR project for measuring party positions because they avoid problems that result from calculating positions based on absolute proportions of sentences on each side of a policy dimension. Lowe et al. (2011a)'s technique alleviates these problems by considering the ratio of sentences on the 'right' to those on the 'left' of a particular policy dimension and assessing this with a logarithmic scale in which the marginal effect of an extra sentence declines as the number of sentences increases. Policy scales are calculated according to the following equation (Lowe et al. 2011a: 131):

$$
\text { Policy scale }=\ln \frac{R+0.5}{L+0.5}
$$

where $R$ is the total number of sentences in the manifesto under codes on the right-wing side of the scale and $L$ is the equivalent figure for codes assigned to the left. Two further advantages of this approach are that Lowe et al. (2011b) offer a wide range of policy scales and that new policy scales can be created based on the MARPOR data, allowing a closer fit between ministries' policy areas and measures of position than with currently available expert judgement data.

We measure divisiveness as zero if a question is directed to a department run by the 
MPs own party, and as the absolute value of the gap in positions between the two partners where a question is directed at a ministry run by the other party in the coalition. Our choices of policy scales for each department and the absolute value of gaps between the parties on these scales are shown in Table 1. Details of the two new scales we created are in Table S1. In our Supplementary Material we provide an explanation for our choice of policy scale-ministry links along with robustness tests using alternative policy scales where these are appropriate and available. Our measure of policy divisiveness allows us to test the extent to which more PQs are asked of departments where the coalition partners are further apart ideologically. In these cases, we would expect a greater need for parties to keep tabs on their coalition partner.

We control for other factors that might explain levels of written questions by MPs to particular departments. First, we take account of the salience of each department's policy area for the party of the MP asking the question. To operationalise this, we use the measures of policy importance developed by Lowe et al. (2011a) based on MARPOR data (Volkens et al. 2017). ${ }^{6}$ We expect that MPs will ask more questions on policy areas that are salient for their party as they are likely to have higher levels of interest in these policy areas. Second, as a measure of the significance of government departments more broadly, we use the percentage of public expenditure going to each department (HM Treasury 2011: 27). We expect higher levels of questioning of those departments that take up higher proportions of government spending. Third, we control for a series of MP-level factors, one of which is a measure of Euroscepticism. Divisions over European integration have long been present in the Conservative Party (e.g. Lynch 1999) and were felt particularly strongly during the 2010-15 Parliament (Lynch and Whitaker 2013). Backbench Conservative MPs who feel their party leadership is far from their own position on the European Union (EU) may be inclined to ask more questions of departments regardless of whether they are run by Conservative or Liberal Democrat ministers, fearing that policy in a range of areas might be pulled away from their own preferences as a result of legislation introduced at EU level. Some evidence of this is provided in Table 3 which shows the individuals who asked the most questions among MPs from the coalition parties during the 2010-15 term. Conservatives top the list, which includes prominent Eurosceptics (Philip Davies, Priti Patel and Zac Goldsmith) as well as those often viewed as being among the furthest right in the Conservative Party (Priti Patel, Andrew Rosindell) and backbenchers notable for their rebellions against the party whip

\footnotetext{
${ }^{6}$ These are calculated using the same MARPOR codes as with the position measures but are transformed with the following equation:

$$
\text { Policy importance }=\ln \frac{R+L+1}{N}
$$

where $R$ is the total number of sentences in the manifesto under codes on the right-wing side of the scale, $L$ is the equivalent figure for codes assigned to the left, and $\mathrm{N}$ is the total number of sentences in the manifesto (Lowe et al. 2011a: 134).
} 
(Philip Davies).

Table 3: The top Ten Submitters of Written Questions among Conservatives and Liberal Democrats, 2010-15

\begin{tabular}{llr}
\hline Name & Party & Number of questions asked \\
\hline Andrew Rosindell & Conservative & 2545 \\
Priti Patel & Conservative & 2172 \\
Philip Davies & Conservative & 1762 \\
David Amess & Conservative & 1465 \\
Zac Goldsmith & Conservative & 1415 \\
Nicholas Soames & Conservative & 1354 \\
Simon Kirby & Conservative & 1138 \\
Bob Russell & Liberal Democrat & 950 \\
Matthew Offord & Conservative & 923 \\
Adrian Sanders & Liberal Democrat & 883 \\
\hline
\end{tabular}

We measure Euroscepticism with a binary variable that captures whether an MP voted for a motion regretting the absence of legislation to provide a referendum on the UKs membership of the EU in the Queens Speech of May 2013 (data are taken from publicwhip.org.uk). This was a free vote and so gives a much better indication of MPs' preferences regarding European integration than a vote controlled by the party leadership (Hanretty et al. 2017).

MPs' behaviour may also be affected by their sense of electoral vulnerability. Following Kellermann (2016) we expect that those who were elected by slimmer margins may feel a greater need to ask PQs in order to demonstrate their parliamentary activity to constituents. We measure each MP's majority as the difference in percentage points between the vote share achieved by the winner and the candidate in second place. We expect higher levels of questioning to be associated with lower majorities. ${ }^{7}$ An MP's length of service in the House of Commons may also affect their questioning behaviour. Those with more time in the House may feel less need to ask PQs in that they may feel more secure in their positions. We measure this with time served (in years) as a member of the House of Commons for each MP by the beginning of the 2010-15 term. On the basis that there is some evidence of women acting differently to men in legislatures and of different views of representational roles among women (Taylor-Robinson 2017: 252253), we control for whether MPs are male or female. ${ }^{8}$ We include a dummy variable

\footnotetext{
${ }^{7}$ Data on electoral majorities are taken from the British Election Study 2015 Constituency Results Version 2.0. (DOI: 10.13140/RG.2.1.1162.1844) and supplemented with data from Wikipedia for MPs elected in by-elections during the 2010-15 Parliament.

${ }^{8} \mathrm{We}$ considered controlling for whether an MP's party has a junior minister in the department to which their questions are addressed. Measuring this would allow us to control for an alternative coalition monitoring mechanism (Thies 2001). We opted not to include such a measure as there is little variation in the allocation of junior ministers. All ministries had Conservative ministers present throughout the 2010-15 Parliament and only the Northern Ireland department had no Liberal Democrat representation at any point during the coalitions lifetime.
} 
for Parliamentary Private Secretaries (PPSs) in our analysis. ${ }^{9}$ The PPS position is the bottom rung on the government ladder and is unpaid. The Ministerial Code (Cabinet Office 2016) states that PPSs are not permitted to ask PQs of the department in which they are based, but they may ask them of others. We expect PPSs to ask fewer questions than other MPs due not only to restrictions placed on them by the Ministerial Code but also on the basis that their role in government gives them a stake in the continuation of the coalition. We also include a control for whether an MP served the full 2010-15 term on the basis that those who were present for less time had fewer opportunities to ask questions. Descriptive statistics for all the variables used in our analysis can be found in Table S3 in the Supplementary Material.

Our dependent variable is composed of count data. The Poisson regression model, designed for dependent variables that constitute counts, is problematic as our data are over-dispersed, meaning that the conditional variance of the dependent variable is greater than the conditional mean. In this situation, the appropriate approach is to use the negative binomial regression model (Long 1997: 230), which includes an estimate of the over-dispersion in the data (reported in Table 4). However, our dependent variable also includes a very large number of zeros (2730 cases of a total of 6308). We take account of this by using a zero-inflated model (Long 1997: 243), one part of which (estimated as a logit model) allows us to specify the variables that we expect to explain whether a case scores zero or not. For this part of the model, we include dummy variables measuring whether MPs acted as junior ministers or cabinet ministers at some point during the 201015 period. While holding these offices, MPs do not ask parliamentary questions. The results of our zero-inflated negative binomial regression are shown in Table 4 where the positive dispersion parameter indicates that a Poisson model would not be appropriate.

Our model shows - as expected - that as policy divisiveness increases, MPs ask more questions. This is shown by the positive and statistically significant coefficient for the policy divisiveness variable. We take this to be evidence that governing MPs are using PQs, at least partially, to keep tabs on coalition partners. Figure 1 shows the substantive effect of policy divisiveness on the numbers of questions asked. Moving from 0 to the maximum value of policy divisiveness on our dataset (3.89) leads to the number of questions asked almost doubling, from 7.3 to 14.2. While this may appear modest, if we compare it with the average number of questions asked in individual cases in our analysis, 9.01, the change is not insubstantial. Similarly, when compared with the average number of questions asked to each department (shown in the rightmost column of Table 1), our prediction of 14 questions for the maximum policy gap, is at or above the average

\footnotetext{
${ }^{9}$ Data on PPSs were taken from an official list published by the Government in November 2010 and available here: https://www.gov.uk/government/news/ government-publishes-list-of-parliamentary-private-secretaries-pps. No other reliable data on PPSs are available for the rest of the 2010-15 term so it is possible that we have not included some individuals who went on to hold PPS positions later in the 2010-15 Parliament.
} 
Table 4: Zero-inflated Negative Binomial Regression Model of Parliamentary Questions

\begin{tabular}{|c|c|c|}
\hline Variable & Coefficient & Standard error \\
\hline \multicolumn{3}{|l|}{ Negative binomial count model } \\
\hline Policy divisiveness & $0.17^{* * *}$ & 0.04 \\
\hline \multicolumn{3}{|l|}{ Controls: } \\
\hline Policy importance & $0.30^{* * *}$ & 0.03 \\
\hline Eurosceptic & $0.54^{* * *}$ & 0.05 \\
\hline Female & 0.09 & 0.06 \\
\hline Majority size & 0.00 & 0.00 \\
\hline Time served as MP (in years) & $-0.01 * * *$ & 0.00 \\
\hline Did not serve full term & $-0.90 * * *$ & 0.18 \\
\hline Parliamentary private secretary & $-0.20 * * *$ & 0.07 \\
\hline Department percentage of public expenditure & $0.04^{* * *}$ & 0.00 \\
\hline Constant & $2.82^{* * *}$ & 0.09 \\
\hline \multicolumn{3}{|l|}{ Zero-inflation logit model } \\
\hline Cabinet minister & $3.37^{* * *}$ & 0.15 \\
\hline Junior minister & $1.68^{* * *}$ & 0.13 \\
\hline Constant & $-2.60 * * *$ & 0.12 \\
\hline$n$ & 6308 & \\
\hline Dispersion parameter & 2.31 & \\
\hline Likelihood ratio $\chi^{2}$ test & $435.12 * * *$ & \\
\hline
\end{tabular}

figure for all departments except for Health.

Our control for the importance of a ministry's policies to the questioner's party has the expected positive effect and is statistically significant, demonstrating that MPs ask more questions of departments on which their party places higher priority. Our control for MPs' Euroscepticism is positive and statistically significant. As we expected, Eurosceptic MPs ask more questions than others. Both of these results suggest the need for further research on intra-party questioning patterns, something we return to in the conclusion. Our controls for female MPs and electoral majority show no statistically reliable effects. The lack of findings for electoral marginality differs from Kellermann (2016)'s results. We suggest this is because our dependent variable measures questioning to specific departments rather than simply numbers of questions asked by each MP regardless of department, as in Kellermann (2016)s work. We find that MPs who have served for longer time periods ask fewer questions, consistent with our expectations that such MPs would feel less pressure to ask PQs on the basis of their more secure position in parliament. We also find the share of public expenditure taken up by a department has the expected effect with more questioning of departments that take up larger shares of the budget. MPs not serving a full term ask fewer questions than others, as we expected, and PPSs ask fewer questions than do other MPs, suggesting their position in government 
Figure 1: The effect of policy divisiveness on the number of questions asked of partner party ministries

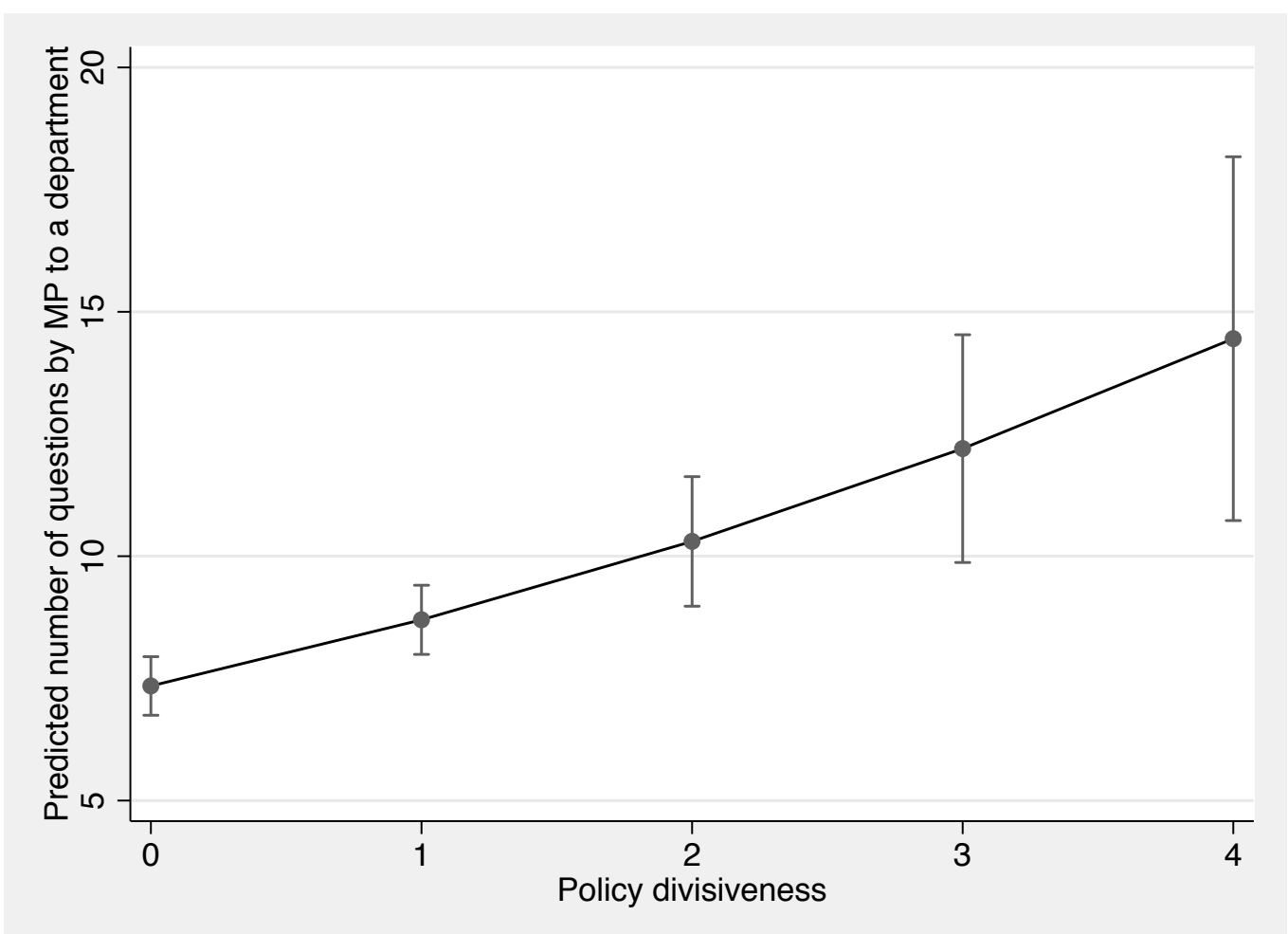

Notes: the vertical bars show $95 \%$ confidence intervals. All other variables have been set at their mean values except for dummy variables which have been set at their modal values.

makes them less likely to question their government colleagues. The zero-inflated logit part of our model shows positive and statistically significant effects on the likelihood of asking no questions of a department for those who have spent time as a junior or cabinet minister, as we anticipated.

\section{Conclusion}

Coalition governments require otherwise competitive political parties to compromise on their policy preferences, with individual ministers charged with implementing the coalition compromise. The result is a classic delegation problem, with parties in coalition government needing to keep tabs on each other to minimize agency loss. A number of expost mechanisms permit parties to police the bargain, including the strategic allocation of junior ministers and the presence of strong committees within the legislature (Martin and Vanberg 2014; Strøm et al. 2010).

This paper aimed to contribute in two ways to the literature on legislatures and coalitions. First, we stress the importance of various legislative institutions as a mechanism to police the coalition bargain. Specifically, we suggest that parliamentary questions are another potential instrument for coalition parties to attempt to monitor their partners. We 
provide evidence that coalition dynamics affect questioning behaviour. Second, we highlight the role of the British House of Commons - generally considered a weak parliament (with weak committees) in a political system with few recent coalition governments - in responding to the emergence of a coalition government following the 2010 general election. Our evidence indicates that the idea of using the legislature to keep tabs on coalition partners applies even in the case of the British House of Commons. More generally, the suggestion is that 'policing the bargain' behaviour within coalition governments can exist in ways not previously considered by scholars. Monitoring behaviour seems to take place particularly in areas where there are relatively high levels of conflict between coalition partners, in this case areas such as health (where the Conservatives implemented reforms, the details of which had not been set out in their electoral manifesto), other welfare state policies, defence and home affairs policies with implications for civil liberties.

What can we conclude from our study about the ability of the British Parliament to enforce coalition agreements? PQs certainly provide an opportunity for coalition monitoring at Westminster (and, we speculate, in any legislature with a system of PQs). Of course, our focus on PQs as a monitoring tool can be set against now conventional wisdom in comparative legislative studies that committees are the (our emphasis) means by which parliament can hold an executive accountable (à la Strøm 1990) and the mechanism by which parties in coalition government can use legislatures to keep tabs on each other (à la Martin and Vanberg 2011; André et al. 2016).

We view PQs as a complimentary good (goods which are or can be used together) to committee systems rather than a pure substitute good (alternative goods that compete to be used for the same purpose). Certainly, in theory PQs and committees can be substitute goods. Our overall assessment is that PQs do provide a mechanism in the UK Parliament for parties in coalition government to keep tabs on each other. But we do not disagree with the notion that increasing the capacity of legislative committees would increase the capacity of a legislature to undertake its oversight function (either on the executive as a whole or as a form of inter-coalition monitoring). And we should not discount the anticipatory effect of PQs - just knowing that MPs can extract information from a particular ministry has, we suspect, a very strong anticipatory effect in keeping ministers in line (either generally or in terms of coalition politics). The British Government may not operate behind a glass wall - but Ministers are surely conscious that Parliament, not least through the system of PQs - can extract information on ministerial actions and inactions and through this hold ministers to account. Our findings thus provide further evidence for recent research that demonstrates how backbench MPs at Westminster can influence public policy through intra-party consultations, amendments to legislation and committee roles (Russell and Gover 2017; Russell and Cowley 2016). This work suggests that the UK Parliament does have mechanisms for influence which can be found by looking beyond simplistic measures such as bill amendment success for backbenchers. 
A number of opportunities to extend the research exist. Moves beyond the research presented here include assessing how far opposition parties target questions strategically to emphasize or increase tensions between coalition partners. Second, we need to understand the multiple functions of questions, even in a party centred electoral environment. In candidate-centred electoral environments, parliamentary questions can be a tool for constituency activity (Martin 2011c). Third, each parliamentary party is itself a coalition of interests and preferences (Müller and Strøm 1999). From this perspective, it is worth exploring intra-party aspects of PQs beyond our Euroscepticism measure. For example, does belonging to a particular faction of the Conservative party predict which Conservative MPs question which Conservative ministers? Finally, comparative, crossinstitutional, research is required to test the generalizability of our argument. PQs are a feature of almost all national legislatures. As PQs are just one of many coalition monitoring tools, we need to understand the relative popularity of these various tools to facilitate coalition government in different political systems.

\section{References}

André, A., Depauw, S., and Martin, S. (2016). Trust Is Good, Control Is Better: Multiparty Government and Legislative Organization. Political Research Quarterly, 69(1):108-120.

Bakker, R., de Vries, C., Edwards, E., Hooghe, L., Jolly, S., Marks, G., Polk, J., Rovny, J., Steenbergen, M., and Vachudova, M. A. (2015). Measuring party positions in Europe: The Chapel Hill expert survey trend file, 19992010. Party Politics, 21(1):143-152.

Bates, S. R., Kerr, P., Byrne, C., and Stanley, L. (2014). Questions to the Prime Minister: A comparative study of PMQs from thatcher to Cameron. Parliamentary Affairs, $67(2): 253-280$.

Bevan, S. and John, P. (2016). Policy Representation by Party Leaders and Followers: What Drives UK Prime Minister's Questions? Government and Opposition, 51(1):125 .

Bird, K. (2005). Gendering Parliamentary Questions. The British Journal of Politics and International Relations, 7(3):353-370.

Cabinet Office (2016). The Ministerial Code. Cabinet Office, London.

Carroll, R. and Cox, G. W. (2012). Shadowing Ministers: Monitoring Partners in Coalition Governments. Comparative Political Studies, 45(2):220-236. 
Cox, G. W. (1987). The Efficient Secret: The Cabinet and the Development of Political Parties in Victorian England. Cambridge University Press, Cambridge.

Cox, G. W. (2006). The Organization of Democratic Legislatures. In Wittman, D. A. and Weingast, B. R., editors, The Oxford Handbook of Political Economy, pages 141-161. Oxford University Press, Oxford.

Franklin, M. N. and Norton, P., editors (1993). Parliamentary Questions. Oxford University Press, Oxford.

Hanretty, C., Lauderdale, B. E., and Vivyan, N. (2017). Dyadic Representation in a Westminster System. Legislative Studies Quarterly, 42(2):235-267.

Hazell, R. and Yong, B. (2012). The Politics of Coalition: How the Conservative-Liberal Democrat Government Works. Bloomsbury Publishing, London.

HM Treasury (2011). Public Expenditure. Statistical Analyses 2011, CM 8104. HM Treasury, London.

Huber, J. D. and Shipan, C. R. (2002). Deliberate Discretion?: The Institutional Foundations of Bureaucratic Autonomy. Cambridge University Press, Cambridge.

Kam, C. J. (2009). Party Discipline and Parliamentary Politics. Cambridge University Press, Cambridge.

Kellermann, M. (2016). Electoral vulnerability, constituency focus, and parliamentary questions in the house of commons. British Journal of Politics and International Relations, 18(1):90-106.

Kelso, A. (2009). Parliamentary Reform at Westsminster. Manchester University Press, Manchester.

Kolpinskaya, E. (2017). Substantive Religious Representation in the UK Parliament: Examining Parliamentary Questions for Written Answers, 1997-2012. Parliamentary Affairs, 70(1):111-131.

Krehbiel, K. (1991). Information and Legislative Organization. University of Michigan Press, Ann Arbor, MI.

Kreppel, A. (2014). Typologies and Classifications. In Martin, S., Saalfeld, T., and Strøm, K., editors, Oxford Handbook of Legislative Studies, pages 82-102. Oxford University Press, Oxford.

Laver, M. and Shepsle, K. A., editors (1994). Cabinet Ministers and Parliamentary Government. Cambridge University Press, Cambridge. 
Laws, D. (2016). Coalition: The Inside Story of the Conservative-Liberal Democrat Coalition Government. Biteback Publishing, London.

Lijphart, A. (2012). Patterns of Democracy: Government Forms and Performance in Thirty-six Countries. Yale University Press, New Haven.

Long, J. S. (1997). Regression Models for Categorical and Limited Dependent Variables. Sage, London.

Lowe, W., Benoit, K., Mikhaylov, S., and Laver, M. (2011a). Scaling Policy Preferences from Coded Political Texts. Legislative Studies Quarterly, 36(1):123-155.

Lowe, W., Benoit, K., Mikhaylov, S., and Laver, M. (2011b). The Manifesto Project data extended to include the logit scales and standard errors.

Lynch, P. (1999). The Politics of Nationhood: Sovereignty, Britishness and Conservative Politics. Palgrave, Basingstoke.

Lynch, P. and Whitaker, R. (2013). Rivalry on the Right: The Conservatives, the UK Independence Party (UKIP) and the EU Issue. British Politics, 8(3):285-312.

Martin, L. W. (2004). The Government Agenda in Parliamentary Democracies. American Journal of Political Science, 48(3):445-461.

Martin, L. W. and Vanberg, G. (2004). Policing the Bargain: Coalition Government and Parliamentary Scrutiny. American Journal of Political Science, 48(1):13-27.

Martin, L. W. and Vanberg, G. (2005). Coalition Policymaking and Legislative Review. American Political Science Review, 99(1):93-106.

Martin, L. W. and Vanberg, G. (2011). Parliaments and Coalitions: The Role of Legislative Institutions in Multiparty Governance. Oxford University Press, Oxford.

Martin, L. W. and Vanberg, G. (2014). Legislative Institutions and Coalition Government. In Martin, S., Saalfeld, T., and Strøm, K., editors, Oxford Handbook of Legislative Studies. Oxford University Press, Oxford.

Martin, S. (2011a). Electoral Institutions, the Personal Vote, and Legislative Organization. Legislative Studies Quarterly, 36(3):339-361.

Martin, S. (2011b). Parliamentary Questions, the Behaviour of Legislators, and the Function of Legislatures: An Introduction. The Journal of Legislative Studies, 17(3):259270 .

Martin, S. (2011c). Using Parliamentary Questions to Measure Constituency Focus: An Application to the Irish Case. Political Studies, 59(2):472-488. 
Martin, S. (2014). Committees. In Martin, S., Saalfeld, T., and Strøm, K., editors, The Oxford Handbook of Legislative Studies, pages 325-370. Oxford University Press, Oxford.

McCubbins, M. D. and Schwartz, T. (1984). Congressional Oversight Overlooked: Police Patrols versus Fire Alarms. American Journal of Political Science, 28(1):165-179.

Müller, W. and Strøm, K. (1999). Policy, Office, or Votes?: How Political Parties in Western Europe Make Hard Decisions. Cambridge University Press, Cambridge.

Müller, W. C. and Strøm, K. (2003). Coalition Governments in Western Europe. Oxford University Press, Oxford.

Müller, W. C. and Strøm, K. (2008). Coalition Agreements and Cabinet Governance. In Strøm, K., Müller, W., and Bergman T., editors, Cabinets and Coalition Bargaining: The Democratic Life Cycle in Western Europe, pages 59-99. Oxford University Press, Oxford.

Narud, H. and Valen, H. (2008). Coalition Membership and Electoral Performance. In Strøm, K., Müller, W., and Bergman, T., editors, Cabinets and Coalition Bargaining: The Democratic Life Cycle in Western Europe, pages 369-402. Oxford University Press, Oxford.

Norton, P. (2013). Parliament in British Politics. Palgrave, London, second edition.

Page, R. (2015). The Coalition, Poverty and Social Security. In Beech, M. and Lee, S., editors, The Conservative-Liberal Coalition: Examining the Cameron-Clegg Government, pages 68-85. Palgrave, Basingstoke.

Proksch, S. O. and Slapin, J. B. (2011). Parliamentary questions and oversight in the European Union. European Journal of Political Research, 50(1):53-79.

Quinn, T., Bara, J., and Bartle, J. (2011). The UK Coalition Agreement of 2010: Who Won? Journal of Elections, Public Opinion and Parties, 21(2):295-312.

Rozenberg, O. and Martin, S. (2011). Questioning Parliamentary Questions. The Journal of Legislative Studies, 17(3):394-404.

Russell, M. (2011). Never Allow A Crisis To Go To Waste': The Wright Committee Reforms to Strengthen the House of Commons. Parliamentary Affairs, 64(4):612-633.

Russell, M. and Cowley, P. (2016). The Policy Power of the Westminster Parliament: The Parliamentary State and the Empirical Evidence. Governance, 29(1):121-137. 
Russell, M. and Gover, D. (2017). Legislation at Westminster. Oxford University Press, Oxford.

Russell, M., Gover, D., and Wollter, K. (2016). Does the Executive Dominate the Westminster Legislative Process?: Six Reasons for Doubt. Parliamentary Affairs, 69(2):286308.

Russo, F. and Wiberg, M. (2010). Parliamentary Questioning in 17 European Parliaments: Some Steps towards Comparison. The Journal of Legislative Studies, 16(2):215232 .

Saalfeld, T. (2000). Members of parliament and governments in western Europe: Agency relations and problems of oversight. European Journal of Political Research, 37(3):353376.

Saalfeld, T. (2011). Parliamentary Questions as Instruments of Substantive Representation: Visible Minorities in the UK House of Commons, 200510. The Journal of Legislative Studies, 17(3):271-289.

Saalfeld, T. and Bischof, D. (2013). Minority-Ethnic MPs and the Substantive Representation of Minority Interests in the House of Commons, 20052011. Parliamentary Affairs, 66(2):305-328.

Schelling, T. (1960). The Strategy of Conflict. Harvard University Press, Cambridge MA.

Strøm, K. (1990). A Behavioral Theory of Competitive Political Parties. American Journal of Political Science, 34(2):565-598.

Strøm, K. (2000). Delegation and accountability in parliamentary democracies. European Journal of Political Research, 37(3):261-289.

Strøm, K., Müller, W. C., and Smith, D. M. (2010). Parliamentary Control of Coalition Governments. Annual Review of Political Science, 13(1):517-535.

Taylor-Robinson, M. (2017). Gender and Legislatures. In Martin, S., Saalfeld, T., and Strøm, K., editors, The Oxford Handbook of Legislative Studies. Oxford University Press, Oxford.

Thies, M. F. (2001). Keeping Tabs on Partners: The Logic of Delegation in Coalition Governments. American Journal of Political Science, 45(3):580-598.

Volkens, A., Lehmann, P., Mattheiß, T., Merz, N., Regel, S., and Werner, A. (2016). The Manifesto Data Collection. Manifesto Project (MRG/CMP/MARPOR). 
Volkens, A., Lehmann, P., Mattheiß, T., Merz, N., Regel, S., and Weßels, B. (2017). The Manifesto Data Collection. Manifesto Project (MRG/CMP/MARPOR).

Wiberg, M., editor (1994). Parliamentary Control in the Nordic Countries: Forms of Questioning and Behavioural Trends. The Finnish Political Science Association, Jyväskylä.

Zubek, R. (2015). Coalition Government and Committee Power. West European Politics, 38(5):1020-1041. 


\section{Supplementary Material}

Table S1: New additive scales created for the Foreign Office and Department for Environment, Food and Rural Affairs

\begin{tabular}{lll}
\hline & Right position & Left position \\
\hline Foreign Office & per102 Foreign special relationships & per101 Foreign special relationships \\
& negative + per104 Military positive & positive + per105 Military negative \\
& + per109 Internationalism negative & + per107 Internationalism positive \\
& + per110 European Union negative & + per108 European Union positive \\
\hline Environment, Food and & $\begin{array}{l}\text { per410 Economic growth positive }+ \\
\text { Rural Affairs }\end{array}$ & per501 Environmental protection + \\
& per703 Agriculture and farmers pos- & per416 Anti-growth economy posi- \\
& itive & tive \\
\hline
\end{tabular}

Table S2: Descriptive statistics

\begin{tabular}{lccrcc}
\hline Variable & Min & Max & Mean & Standard deviation & $\mathrm{n}$ \\
\hline $\begin{array}{l}\text { Number of questions asked by MP } \\
\text { to specific department (dependent }\end{array}$ & 0 & 744 & 9.12 & 25.41 & 6308 \\
variable) & & & & \\
Policy divisiveness & 0 & 3.89 & 0.36 & 0.69 & 6308 \\
Salience of departmental policy for & -7.01 & -0.98 & -3.02 & 1.12 & 6308 \\
questioner's party & & & & & \\
Female & 0 & 1 & 0.14 & 0.35 & 6308 \\
Eurosceptic & 0 & 1 & 0.35 & 0.48 & 6308 \\
Majority size & 0.1 & 43.7 & 18.16 & 11.17 & 6308 \\
Time served as MP (in years) & 0 & 49.12 & 7.32 & 9.06 & 6308 \\
Departmental share of public expen- & 0.5 & 27.6 & 5.24 & 6.57 & 6308 \\
diture & & & & & \\
Did not serve full term & 0 & 1 & 0.02 & 0.12 & 6308 \\
Parliamentary Private Secretary & 0 & 1 & 0.13 & 0.33 & 6308 \\
Junior minister & 0 & 1 & 0.33 & 0.47 & 6308 \\
Cabinet minister & 0 & 1 & 0.12 & 0.32 & 6308 \\
\hline
\end{tabular}

\section{Explanation for choice of policy scales for particular departments and robustness tests}

The Lowe et al. (2011b) measures that we employ for measuring the policy positions of parties are derived from MARPOR Data (Volkens et al. 2016) and offer a wider choice than scales derived from expert judgement data. We selected the most appropriate scale given our knowledge of the responsibilities of each ministry and the legislation emerging from each during the 2010-15 period. In most cases there was an obvious choice. Constitutionalism is used for questions to the Deputy Prime Minister (DPM) as this was the policy brief taken on by the DPM (and Liberal Democrat leader) Nick Clegg. We selected the nationalism scale for the Home Office to reflect the divisions between the 
coalition partners over how to deal with immigration and related issues. The free market economy measure was chosen for health on the basis that the main legislation from this department under the 2010-15 government (the Health and Social Care Act 2012) involved changes with regard to the role of private providers in services provided by the National Health Service. The choice of the decentralisation scale for the departments dealing with Scotland, Wales and Northern Ireland reflects legislation passed under the coalition government (e.g. the Scotland Act 2012, the Wales Act 2014) in each case that altered the powers of legislative assemblies and executives.

For some departments our choices were restricted because (a) not all policy areas are covered in the MARPOR coding scheme and (b) for some issues, there are codes for only one side of a debate. Use of scales in these cases is problematic because our measure becomes essentially one of salience, in which the measure would be based on how much of the manifesto is dedicated to the policy area, rather than one of position, where we calculate the ratio of positive to negative statements in the manifesto on the issue in question (Lowe et al. 2011a: 131). For instance, we were unable to obtain a transport-specific measure as the manifesto data record only positive mentions of transport and infrastructure. The same situation applies in the case of culture. For these two departments, we chose the next most appropriate scale from those available, namely, the free market economy measure, given that much legislation from these ministries was concerned with government intervention in particular activities under these two policy areas.

In order to assess how far our results are affected by particular policy scale-department combinations, we test the effects of employing alternative measures for those ministries where a feasible alternative was available. Table S3 shows measures used in the main model and, where an appropriate alternative was available, the different measures we use in our robustness tests. Results of these tests are presented in Table S4.

As is clear from Table S4 our results remain robust to changes in measures of policy for particular departments. We find a statistically significant and positive coefficient for policy divisiveness in all cases. In one case (using the social-liberal conservative scale for the Home Office) the significance level for this variable is reduced to $p=0.069$. 
Table S3: Policy scales used to measure party positions for ministries and appropriate alternatives where available

\begin{tabular}{lll}
\hline Department & Lowe et al. (2011a) or new scale & Alternative \\
\hline Deputy Prime Minister & Constitutionalism & None \\
Foreign Office & Foreign office* & None \\
Treasury & State involvement in economy & None \\
Justice & Social-Liberal Conservative & None \\
Home Office & Nationalism & Social-liberal Conservative \\
Defence & Militarism & None \\
Business, Innovation and Skills & Free market economy & None \\
Work and Pensions & Welfare state & None \\
Energy and Climate Change & Environmental protection & None \\
Health & Free market economy & Welfare state \\
Education & Education spending & None \\
Communities and Local Govt & Decentralisation & Multiculturalism \\
Transport & Free market economy & None \\
Environment, Food and Rural & Environment and agriculture* & Standard \\
Affairs & & environmentalism measure \\
International Development & Internationalism & None \\
Northern Ireland & Decentralisation & Right-left scale (RILE) \\
Scotland & Decentralisation & RILE \\
Wales & Decentralisation & RILE \\
Culture, Olympics, Media and & Free market economy & None \\
Sport & & \\
\hline
\end{tabular}

Table S4: Models of parliamentary questions using alternative measures of position and salience for government ministries

\begin{tabular}{|c|c|c|c|c|c|}
\hline & $\begin{array}{c}\text { Health } \\
\text { (welfare state) }\end{array}$ & $\begin{array}{l}\text { Home affairs } \\
\text { (social lib-cons) }\end{array}$ & $\begin{array}{c}\text { Communities } \\
\text { (multiculturalism) }\end{array}$ & $\begin{array}{c}\text { EFRA } \\
\text { (env'lism only) }\end{array}$ & $\begin{array}{l}\text { NI, Scot, Wales } \\
\text { (Right-left) }\end{array}$ \\
\hline \multicolumn{6}{|l|}{$\begin{array}{l}\text { Negative binomial count } \\
\text { model }\end{array}$} \\
\hline Policy divisiveness & $0.17^{* * *}$ & $0.06^{*}$ & $0.08^{* * *}$ & $0.16^{* * *}$ & $0.14^{* * *}$ \\
\hline \multicolumn{6}{|l|}{ Controls: } \\
\hline Policy importance & $0.30^{* * *}$ & $0.25^{* * *}$ & $0.19^{* * *}$ & $0.29 * * *$ & $0.23^{* * *}$ \\
\hline Eurosceptic & $0.54^{* * *}$ & $0.53^{* * *}$ & $0.54^{* * *}$ & $0.54^{* * *}$ & $0.55^{* * *}$ \\
\hline Female & 0.09 & 0.08 & 0.08 & 0.09 & 0.10 \\
\hline Majority size & 0.00 & 0.00 & 0.00 & 0.00 & 0.00 \\
\hline Time served as MP (in years) & $-0.01 * * *$ & $-0.01 * * *$ & $-0.01 * * *$ & $-0.01 * * *$ & $-0.01 * * *$ \\
\hline Did not serve full term & $-0.90 * * *$ & $-0.96 * * *$ & $-0.93^{* * *}$ & $-0.90 * * *$ & $-0.90 * * *$ \\
\hline $\begin{array}{l}\text { Parliamentary private } \\
\text { secretary }\end{array}$ & $-0.20 * * *$ & $-0.18 * * *$ & $-0.20 * * *$ & $-0.20 * * *$ & $-0.21 * * *$ \\
\hline Dept $\%$ of public expenditure & $0.04^{* * *}$ & $0.05^{* * *}$ & $0.04^{* * *}$ & $0.04^{* * *}$ & $0.04^{* * *}$ \\
\hline Constant & $2.82^{* * *}$ & $2.69^{* * *}$ & $2.57^{* * *}$ & $2.80 * * *$ & 2.60 \\
\hline \multicolumn{6}{|l|}{ Zero-inflation logit model } \\
\hline Cabinet minister & $3.38^{* * *}$ & $3.36^{* * *}$ & $3.35^{* * *}$ & $3.37^{* * *}$ & $3.38^{* * *}$ \\
\hline Junior minister & $1.68^{* * *}$ & $1.67 * * *$ & $1.66^{* * *}$ & $1.67 * * *$ & $1.68^{* * *}$ \\
\hline Constant & $-2.61 * * *$ & $2.69^{* * *}$ & $2.57^{* * *}$ & $2.80^{* * *}$ & 2.60 \\
\hline $\mathrm{n}$ & 6308 & 6308 & 6308 & 6308 & 6308 \\
\hline Dispersion parameter & 2.31 & 2.28 & 2.23 & 2.32 & 2.34 \\
\hline Likelihood ratio $\chi^{2}$ test & $433.98 * * *$ & $484.39 * * *$ & $394.94 * * *$ & $427.23 * * *$ & 398.16 *** \\
\hline
\end{tabular}

Note: policy divisiveness is based on measures taken from the Lowe et al. (2011a) transformations of the 2010 MARPOR data (Volkens et al. 2016). Column headings indicate the ministry for which an alternative measure has been tested with the name of the alternative measure in parentheses. Abbreviations: EFRA: Environment, Food and Rural Affairs; NI: Northern Ireland. 